\title{
Comparative Optimality Theory Analysis of Primary Stress Assignment in Standard British and Nigerian English
}

\author{
Gideon S. Omachonu \\ Nasarawa State University
}

\begin{abstract}
This work presents a comparative optimality account of primary stress assignment in Standard British English (SBE) and Nigerian English (NE), particularly from the point of view of Igala users of English as a second language. Data for this study included readymade exercises and already recorded cassettes, which deal directly with primary stress assignment in SBE. This is in addition to the researcher's knowledge of these varieties of English, his choice of a native speaker of SBE as a language helper as well as useful pieces of information collated using wordlists. The method for elicitation of segments was mainly perceptual. The study has demonstrated how the constraint ordering in Standard British English is 'naturally' reordered in Nigerian English observing that the different constraint orderings notwithstanding, these constraints are the same, and are present in each of these varieties. It has shown also that Optimality Theory satisfies the requirement that any serious theory of phonology must rely heavily on well-formedness constraints, which means it must be committed to universal grammar, a fact that places the theory at an advantage over its predecessors
\end{abstract}

Keywords: Phonology, Optimality Theory, Standard British English, Nigerian English 


\section{Introduction}

The last eight decades or so have seen a substantial change in the nature of phonological theory research. This change has been marked by the development of several new theoretical frameworks (linear and non-linear). In the early 1990s, phonological theory or investigation reached another turning point. Prince \& Smolensky (1993) introduced to the scene another important phonological theory, Optimality Theory (OT), which goes much farther than the phonological theories of the 1970s and 80s. One of the main advantages of the framework, Tesar \& Smolensky (2000) argue, is the rich structure of the grammar space it defines, which in turn enables the child to exploit a type of implicit negative evidence. In other words, the learner can rely on the implicit ungrammaticality of failed competitors to establish constraint rankings (Bermudez-Otero $\&$ Honeybone, 2004). Here, in this framework of Optimality Theory, surface phonology is held to be the result of constraints that enforce stated relationships between inputs (underlying representations) and outputs (surface forms).

Optimality Theory (OT) is not the first to be used in accounting for stress pattern in language including English in particular. Chomsky and Halle (1968) in their landmark publication, Sound Pattern of English (SPE), presented a generative phonology based analysis or approach to stress using tree diagram or Word Boundary Insertion Rule with labeled bracketing. Even though stress is commonly regarded as a suprasegmental phenomenon, this approach treated stress as a property of individual segments, especially the vowels. Consequently, their assignment of stress was determined by sequence of particular segments. ${ }^{1}$ However illuminating the analysis

\footnotetext{
${ }^{1}$ See Hogg \& McCully (1985: 28) for a brief summary of the principal features of the generative phonology account of stress assignment in English.
} 
may be, the earlier generative treatments of English stress as contained in Chomsky \& Halle (1986), Halle \& Keyser (1971) and even Halle (1973) had suffered devastating criticisms as a result of certain obvious limitations. For instance, linguists the world over have accepted the fact that a "syllable based" description of stress patterns would be preferable to "a segment based" description on two grounds: simplicity and adequacy (see Hogg \& McCully 1985). Even when the search for a new, more adequate and more preferable model commenced which eventually located the metrical theory of stress assignment in stress languages, it was not without major challenges and shortcomings

Besides, it is to be noted that even though the non-linear theoretical frameworks (metrical and autosegmental phonology) have handled suprasegmental features relevant to prosodic phonology: syllable and syllable structure, stress and other suprasegmental phenomena like accent, tone and vowel harmony. The OT model is for now adjudged the most current, efficient, viable and dependable because it is seen to have more explanatory force (Prince \& Smolensky, 1993; Oyebade, 1997, 1998; Tesar \& Smolensky, 2000; Bermudez-Otero \& Honeybone, 2004). It is on this conviction, together with the strength of the various advantages of this model enunciated earlier on, that this work seeks to investigate the applicability and or relevance of it to English primary stress assignment. We shall, for the purpose of this study, concentrate on the application of the theory to stress placement in simple English words as it affects these two varieties: SBE and NE.

It may also be worthy of note to state that the experience of the Igala learner or user of English may not be too different from that of other Nigerians especially, the Yoruba and the Itsekiri in this regard; being that the three (Igala, Yoruba and Itsekiri) share a lot of linguistic features in common. However, the observed marked differences or deviations on the part of Nigerian English may not be the exact experience for certain Nigerian learners or users of English, 
especially as one moves up the Nigerian social strata to the standard and, ultimately, the sophisticated; hence the need to limit one's focus to the average Igala learner or user of English as a second language.

\section{Distinguishing Suprasegmental Features of Nigerian English and Standard British}

Comparative studies of varieties of English so far have shown that Nigerian English differs remarkably from Standard British English. A lot has already been done in the areas of lexis, syntax, semantics (including pragmatics) and even segmental phonology (Salami 1969; Jibril 1982; Jowitt 1991; Akindele \& Adegbite 1992, Kujore 1992; Oyebade 2000 \& Akinjobi 2002), but much is still left undone in the area of suprasegmental phonology. Banjo (1979) argues that it is, in most cases the last hurdle which majority of speakers of English as a second language, never manages to cross (see also Akinjobi 2002).

Discussing in detail the markedness of primary stress assignment in Nigerian English, Kujore (1985) argues that the most striking characteristic of Nigerian pronunciation is the 'delayed primary stress'. This feature, he explains, seems to betray the influence of Nigerian indigenous languages with a rising rhythm as against the falling rhythm of Standard British English. His attempt to define stress assignment in Nigerian English ended up in certain rules (see Kujore as cited in Akinjobi, 2002: 41-42).

It has been observed that at word level, the difference between the suprasegmental phonology of Nigerian English (NE) and that of Standard British English (SBE) or the Received Pronunciation (RP) is most salient in the area of primary stress assignment (Jowitt, 1991). First, in disyllabic words, for instance, with the SBE contour $1-2$ (where 1 represents primary stress, and 2, secondary stress), 
there is an NE tendency to reverse the order to 2-1 instead. The examples below clearly illustrate this fact:
(1) SBE 12 эmadam stribune эperfume forfeit эsalad эpublish
NE
21
maэdam
triэbune
perэfume
for Эfeit
sa lad
puэblish

Besides, for a large number of words where SBE has the contour $1-3-2$ (where 3 represents tertiary stress while 1 and 2 represent primary and secondary stress respectively as earlier coded above), NE would prefer 2-3-1 as shown below:

(2)

SBE
$1 \quad 3 \quad 2$
эpanadol
эcinema
эtelephone
эkerosene

NE

$\begin{array}{lll}2 & 3 & 1\end{array}$

panaэdol

cineэma

tele эphone

kero эsene

Similarly, for the configuration, 3-1-2 in SBE, Nigerian English would go for 3-2-1 instead:

(3)
SBE
$\begin{array}{lll}3 & 1 & 2\end{array}$
con stribute
coэmmittee
em $э$ barrass
deэvelop

NE

$\begin{array}{lll}3 & 2 & 1\end{array}$

contriэbute

comm эttee

emba эrrass

deveэlop 
In all, one notices a strong tendency on the part of Nigerian English to shift the primary stress to the right. The result is that single word as well as nuclear stress (NS) is assigned to an undesirable and unsuitable syllable or word in the sentence thereby rendering it unnatural and unacceptable or sometimes, failure to convey the intended meaning. But where the primary stress is naturally to the right in a word especially word or syllable final position in SBE, Nigerian English does not tamper with such:

(4)

\begin{tabular}{|c|c|}
\hline SBE & NE \\
\hline aэpply & aэpply \\
\hline a эrrive & asrrive \\
\hline aэssist & aэssist \\
\hline enter Эtain & enter эtain \\
\hline resuэrrect & resuэrrect \\
\hline
\end{tabular}

These facts, as descriptive as they are, may not give us a truer picture of the actual relationship between these two varieties of English until it receives a theoretical backing because as the saying goes 'practice without theory is as blind as theory without practice is barren' hence the need for the application of OT to vividly explain or show the theoretical basis for the similarities and or differences between these varieties in this regard. Therefore in what follows we shall render an OT account of the data above with a view to showing the natural (universal) relationship between SBE and NE in simple word primary stress assignment and also to attest to the advantage of OT over its predecessors in the analysis of primary stress in English. 


\section{Analysis and Discussion on the Findings Using the OT Framework}

Suffice it to say that a lot of works have been done on stress systems from the late 1970 s to the late 1980 s which, according to Oyebade (1998), gave birth to the non-linear theory of Metrical Phonology. He argues further that many of the insights acquired from these studies were incorporated into Optimality Theory through the establishment of various constraints. Below are the relevant universal conflicting constraints spotted or identified in this regard (see also Prince \& Smolensky 1993; McCarthy \& Prince 1993, 1994; Pulleyblank 1994; Kager 1999):

1. NONFINALITY $=$ No foot is final in PrWd.

2. $\mathrm{UNEVEN}-\mathrm{IAMB}=(\mathrm{LH})>(\mathrm{LL}),(\mathrm{H})$, i.e. $(\mathrm{LH})$ is a better iamb than $(\mathrm{LL} / \mathrm{H})$.

3. $\mathrm{GrWd}=\mathrm{PrWd}=\mathrm{A}$ grammatical word must be a prosodic word.

4. $\mathrm{PARSE}-\mathrm{SYL}=$ Feet are parsed by feet, i.e. a demand that syllables be footed.

5. Weight-Stress-Principle (WSP) $=$ Heavy syllables are stressed.

6. FT-BIN= Feet are binary under moraic or syllabic analysis.

7. ALL-FT-LEFT= Every foot stands at left edge of the PrWd.

8. $\mathrm{DEP}-\mu-\mathrm{IO}=$ Output moras have input correspondents (the anti-lengthening constraint which prefers avoidance of vowel length.

It is to be noted that out of the above eight constraints, only two are going to be prominently relevant in the distinction we are going to make between these varieties or dialects of English. These are NONFINALITY, which constrains the placement of primary stress on the final syllable of a word and UNEVEN-IAMB, which prefers assigning stress on Light-Heavy syllable to Light-Light or Heavy, 
that is, a syllable made up light mora theavy mora instead of light mora + light mora or a single heavy mora. But our English specific analysis let us draw from Kager's as aroad map to where we shall going presently.

Kager (1999), in particular, investigates rhythmic lengthening in Hixkaryana (a stress language of the Cariban family spoken in the Amazon, Northern Brazil) where he delves into a genuine universal metrical system as he tries to spot metrical forces or conflicting universal constraints at work. Consequently, in the light of the available data in Hixkaryana presented in the study, he summarizes the hierarchy of constraint ranking in the language thus: GRWD=PRWD, NONFINALITY, FT-BIN, WSP >> UNEVENIAMB $>>$ PARSE-SYL $>>$ ALL-FT-LEFT $>>$ DEP-U-IO. Kager's analysis illustrates important universal ingredients of the analysis of word stress patterns, that is, the basic metrical constraints and their interactions in producing a rhythmic pattern. The implication of the application of OT analysis in this regard is that stress assignment in any human language (including English) can be accounted for using the above relevant universal constraints. What makes the difference however is the ranking order allowed by individual languages, that is, the resolution of conflicting preferences behind each language, which gives it a distinct identity. With this background, we can now go ahead to present SBE and NE (the average Igala speaker of English's variety) specific ranking of the constraints under a typical metrical system of the English language considering the available data as we analyze stress assignment in the language in the light of the already identified universal constraints.

To start with, we shall look at the first pair of conflicting constraints, that is, the preference for 'canonical iamb' (Light Heavy $=$ LH-UNEVEN-IAMB) versus the preference for 'final syllables to be unstressed' (NONFINALITY) using tables 1a and b below: 
Table 1a. Disyllabic Noun-SBE

Inputs: / 'mædəm, 'tri:bju:n, 'p3:fju:m/

\begin{tabular}{|c|c|c|c|}
\hline No. & & NONFINALITY & UNEVEN-IAMB \\
\hline $\mathrm{a}$ & $\begin{aligned} &(\mathrm{mæ}) \cdot \mathrm{d} \partial \mathrm{m} \\
& \mathrm{m} \partial \cdot(\mathrm{d} m) \\
&(\mathrm{mæ} . \mathrm{d} \partial \mathrm{m})\end{aligned}$ & $\begin{array}{l}* ! \\
* !\end{array}$ & $\begin{array}{l}* \\
*\end{array}$ \\
\hline$b$ & $\begin{array}{l}\text { (tri:) . bju:n } \\
\text { tri: . (bju:n) } \\
\text { (tri: . bju: n) }\end{array}$ & $\begin{array}{l}* ! \\
* !\end{array}$ & $\begin{array}{l}* \\
* \\
*\end{array}$ \\
\hline $\mathrm{c}$ & $\begin{aligned} \text { (p3:). fju:m } \\
\text { pə. (fju:m) } \\
\text { (p3: . fju:m) }\end{aligned}$ & $\begin{array}{l}* ! \\
* !\end{array}$ & * \\
\hline
\end{tabular}

NONFINALITY >> UNEVEN-IAMB

$\leftrightarrow=$ Optimal candidate

Table 1b. Disyllabic Noun-NE

Inputs: / 'mædəm, 'tri:bju:n, 'p3:fju:m/

\begin{tabular}{|c|c|c|c|}
\hline No. & & NONFINALITY & UNEVEN-IAMB \\
\hline A & $\begin{array}{l}\text { (ma). dam } \\
\text { ma. (da:m) } \\
\text { (ma. dam) }\end{array}$ & $*$ & $* !$ \\
\hline B & $\begin{array}{l}\text { (tri) . bun } \\
\text { tri. (bu:n) } \\
\text { (tri . bun) }\end{array}$ & $*$ & $* !$ \\
\hline C & $\begin{array}{l}\text { (pe). fum } \\
\text { p } \text {. (fu:m) } \\
\text { (p } \varepsilon \text {. fum) }\end{array}$ & $*$ & $* !$ \\
\hline
\end{tabular}

NONFINALITY >> UNEVEN-IAMB

$\leftrightarrow$ = Optimal candidate 
100 Comparative Optimality Theory Analysis

As usual, an asterisk in OT analysis means normal violation whereas the exclamatory sign '!' stands for fatal violation. It is observed from the tables above that while in table 1a representing SBE, there is a higher preference for NONFINALITY, on table $1 \mathrm{~b}$ representing the Igala native speaker's variety of Nigerian English, the preference is higher for canonical iamb (UNEVEN-IAMB). This is because as against table 1a where all optional candidates violate UNEVEN-IAMB, on table $1 \mathrm{~b}$ all optional candidates violate NONFINALITY instead, a clear demonstration of the variety's dispreference for initial or first syllable stress placement. Another salient observation worthy of note is the fact that the shift in stress in this regard affects even the vowel qualities of the words involved: e.g. $\mathrm{a} \rightarrow \mathrm{a}:, \mathrm{u} \rightarrow \mathrm{u}$ :, and so on .Notice also the changes $(\mathfrak{a} \rightarrow \mathrm{a}, \mathrm{i}: \rightarrow \mathrm{i}$, $\partial \rightarrow \varepsilon, æ / \partial \rightarrow \mathrm{a}, \partial \rightarrow \supset$ ) on tables $1 \mathrm{~b}$ above and $2 \mathrm{~b}, 3 \mathrm{~b}$, and $4 \mathrm{~b}$ below. This is because such vowels do not exist in Igala. In addition, whereas the dispreference for NONFINALITY amounts to fatal or crucial violation in $\mathrm{SBE}$, it is lower in ranking compared to UNEVEN-IAMB in Nigerian English.

What's more, we shall extend or continue this simple ranking of constraints using the same basic comparative method until we can arrive at a complete characterization of primary stress assignment in both Standard British and this sub-variety of Nigerian English. For instance, an unparsed output (without foot) violates the command that grammatical words must have prosody-a culminative property: $\mathrm{G}_{\mathrm{R}} \mathrm{W}_{\mathrm{D}}=\mathrm{P}_{\mathrm{R}} \mathrm{W}_{\mathrm{D}}$ - a grammatical word must be a prosodic word. By implication, grammatical words by this constraint have minimally one foot. Further to this is the imperative that nodes be properly governed 'or mothered which consequently 'gave rise to the requirement that syllables be properly footed through rhythmic patterning. Consequent upon the above, a conflict arises between especially $\mathrm{G}_{\mathrm{R}} \mathrm{W}_{\mathrm{D}}=\mathrm{P}_{\mathrm{R}} \mathrm{W}_{\mathrm{D}}$, UNEVEN IAMB $>$ or $<<$ NONFINALITY and PARSE-SYL as resolved on tables $2 a$ and $b$ below. 
Table 2a. SBE: Two - Three Syllables (noun and verb)

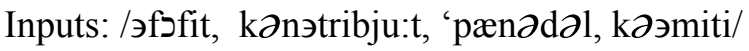

\begin{tabular}{|c|c|c|c|c|c|c|}
\hline No & & & $\begin{array}{c}\mathrm{G}_{\mathrm{R}} \mathrm{W}_{\mathrm{D}}= \\
\mathrm{P}_{\mathrm{R}} \mathrm{W}_{\mathrm{D}}\end{array}$ & $\begin{array}{c}\text { NON- } \\
\text { FINALITY }\end{array}$ & $\begin{array}{l}\text { UNEVEN- } \\
\text { IAMB }\end{array}$ & $\begin{array}{l}\text { PARSE- } \\
\text { SYL }\end{array}$ \\
\hline $\mathrm{a}$ & $\sqrt{\sin }$ & $\begin{array}{l}\text { (fכ:) . fit } \\
\text { (fכ: . fit) } \\
\text { fə. (fi: t) }\end{array}$ & & $\begin{array}{l}* ! \\
* !\end{array}$ & $\begin{array}{l}* \\
*\end{array}$ & $\begin{array}{l}* \\
*\end{array}$ \\
\hline $\mathrm{b}$ & 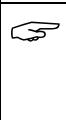 & $\begin{array}{l}\text { kən. (tri). bju:t } \\
\text { (kən). tri. bju:t } \\
\text { kən. tri. (bju:t) }\end{array}$ & & $* !$ & $*$ & $\begin{array}{l}* * \\
* * \\
* *\end{array}$ \\
\hline $\mathrm{c}$ & 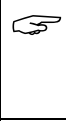 & 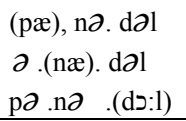 & & $* !$ & * & $\begin{array}{l}* * \\
* * \\
* *\end{array}$ \\
\hline $\mathrm{d}$ & $\sqrt{\infty}$ & 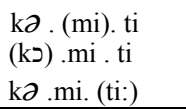 & & *! & $*$ & $\begin{array}{l}* * \\
* * \\
* *\end{array}$ \\
\hline
\end{tabular}

$\mathrm{G}_{\mathrm{R}} \mathrm{W}_{\mathrm{D}}=\mathrm{P}_{\mathrm{R}} \mathrm{W}_{\mathrm{D}}>>$ NONFINALITY $>>$ UNEVEN-IAMB $>>$ PARSE-SYL $=$ Optimal candidate

Table 2b. NE: Two - Three Syllables (noun and verb)

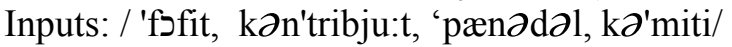

\begin{tabular}{|c|c|c|c|c|c|c|}
\hline No. & & & $\begin{array}{c}\mathrm{G}_{\mathrm{R}} \mathrm{W}_{\mathrm{D}}= \\
\mathrm{P}_{\mathrm{R}} \mathrm{W}_{\mathrm{D}}\end{array}$ & $\begin{array}{c}\text { UNEVEN- } \\
\text { IAMB }\end{array}$ & $\begin{array}{c}\text { NON- } \\
\text { FINALITY }\end{array}$ & $\begin{array}{c}\text { PARSE- } \\
\text { SYL }\end{array}$ \\
\hline $\mathrm{a}$ & $\sqrt{\infty}$ & $\begin{array}{l}\text { (fכ) . fit } \\
\text { (fכ . fit) } \\
\text { fכ. (fi: t) }\end{array}$ & & $\begin{array}{l}* ! \\
* !\end{array}$ & * & $\begin{array}{l}* \\
* \\
\end{array}$ \\
\hline $\mathrm{b}$ & $\operatorname{sis}$ & $\begin{array}{l}\text { kən. (tri). but } \\
(k \supset n) \text {. tri. but } \\
\text { kən. tri. (bu:t) }\end{array}$ & & $* !$ & $*$ & $\begin{array}{l}* * \\
* * \\
* *\end{array}$ \\
\hline $\mathrm{C}$ & $\sqrt{\infty}$ & $\begin{array}{l}\text { (pa). na. dəl } \\
\text { pa.(na). dəl } \\
\text { pa .na .(dכ:1) }\end{array}$ & & *! & $*$ & $\begin{array}{l}* * \\
* * \\
* *\end{array}$ \\
\hline $\mathrm{d}$ & $\sqrt{2}$ & $\begin{array}{l}\mathrm{kJ} \cdot(\mathrm{mi}) \cdot \mathrm{ti} \\
(\mathrm{k} \supset) \cdot \mathrm{mi} \cdot \mathrm{ti} \\
\mathrm{kJ} \cdot \mathrm{mi} \text { (ti:) }\end{array}$ & & $* !$ & $*$ & $\begin{array}{l}* * \\
* * \\
* *\end{array}$ \\
\hline
\end{tabular}

$\mathrm{G}_{\mathrm{R}} \mathrm{W}_{\mathrm{D}}=\mathrm{P}_{\mathrm{R}} \mathrm{W}_{\mathrm{D}}>>$ UNEVEN-IAMB $>>$ NONFINALITY $>>$ PARSE-SYL $\underset{\infty}{\infty}=$ Optimal candidate 
Here still, the difference is that while all the optimal candidates on table 2a satisfy NONFINALITY showing the preference for first or penultimate syllable stress in SBE, all optimal candidates on table $2 \mathrm{~b}$ representing Nigerian English violate NONFINALITY whereas they all satisfy UNEVEN-IAMB, a clear demonstration of their dispreference for the former and a show of preference for the latter. Besides, using the constraint ranking arguments, which are consistent with 'transitivity of strict domination', and the pieces of evidence gathered from the available data so far, we may have to rank $G_{R} W_{D}=P_{R} W_{D}$ together with WSP and FT-BIN at the top of the hierarchy for both SBE and Nigerian English. Constraint ranking arguments, it is to be noted, are consistent with transitivity of strict domination. This means that if there are three constraints $(a, b$ \& c), for instance, with (a) dominating (b) while (b), in turn, dominates (c), it implies that (a) by transitivity of strict domination also dominates (c) - an extended domination which may be double or triple - depending on the position or distance in the hierarchy. By implication, whereas quantity sensitivity in the form of Weight Stress - Principle (WSP) together with the imperative that every $\mathrm{G}_{\mathrm{R}} \mathrm{W}_{\mathrm{D}}$ must have a foot as its head $\left(\mathrm{G}_{\mathrm{R}} \mathrm{W}_{\mathrm{D}}=\mathrm{P}_{\mathrm{R}} \mathrm{W}_{\mathrm{D}}\right)$ ranks highest in English, FT-BIN which encourages avoidance of light feet, recommending the preference for binary feet under moraic or syllabic analysis equals especially WSP in rank. Thus far, the resulting integrated hierarchies of constraints for the two varieties of English could come up in the configurations presented below:

$$
\begin{array}{ll}
\text { SBE: } & \mathrm{G}_{\mathrm{R}} \mathrm{W}_{\mathrm{D}}=\mathrm{P}_{\mathrm{R}} \mathrm{W}_{\mathrm{D}}, \mathrm{WSP}, \text { FT-BIN }>>\text { NONFINALITY } \\
& >>\mathrm{UNEVEN}_{\mathrm{IAMB}}>\text { PARSE-SYL } \\
\text { NE: } & \mathrm{G}_{\mathrm{R}} \mathrm{W}_{\mathrm{D}}=\mathrm{P}_{\mathrm{R}} \mathrm{W}_{\mathrm{D}}, \mathrm{WSP}, \text { FT-BIN }>>\text { UNEVEN-IAMB } \\
& >>\text { NONFINALITY }>\text { PARSE-SYL }
\end{array}
$$

From all indications, especially the available data from both SBE and Nigerian English, it has been observed that it is more important 
to stress heavy syllables than it is for all syllables to be parsed by feet (WSP $>>$ PARSE-SYL). In SBE, in particular, it is a better metrification for foot to be at the left edge-ALL -FT-LEFT than UNEVEN - IAMB and PARSE-SYL put together. Here, a conflict arises among these constraints including NONFINALITY in especially Nigerian English as will be resolved on tables $3 a$ and $b$ below.

Table 3a. SBE: Three-Four Syllables (noun and verb)

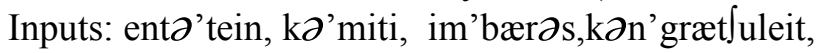
indi'vid3 uəl/

\begin{tabular}{|c|c|c|c|c|c|}
\hline No & & $\begin{array}{c}\text { NON- } \\
\text { FINALITY }\end{array}$ & $\begin{array}{c}\text { ALL- } \\
\text { FT-LEFT }\end{array}$ & $\begin{array}{c}\text { UNEVEN- } \\
\text { IAMB }\end{array}$ & $\begin{array}{c}\text { PARSE- } \\
\text { SYL }\end{array}$ \\
\hline a & 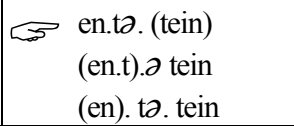 & & $*$ & $\begin{array}{l}* \\
* \\
*\end{array}$ & $\begin{array}{c}* * \\
* \\
* *\end{array}$ \\
\hline $\mathrm{b}$ & 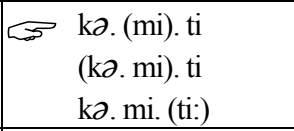 & $*$ & * & * & $\begin{array}{c}* \\
* \\
* * \\
\end{array}$ \\
\hline $\mathrm{c}$ & $\begin{aligned} \text { im. (bæ). rəs } \\
\text { (im. bæ). rəs } \\
\text { im. b.(ræs) }\end{aligned}$ & & * & $*$ & $\begin{array}{c}* * \\
* \\
* * \\
\end{array}$ \\
\hline d & 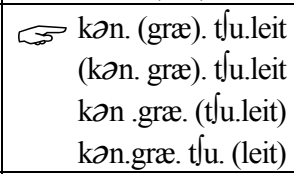 & * & $\begin{array}{l}* \\
* \\
*\end{array}$ & * & $\begin{array}{l}* * * \\
* * \\
* * \\
* * *\end{array}$ \\
\hline $\mathrm{e}$ & $\begin{array}{r}\text { in. di.(vi). d3 ual } \\
\text { (in. di).vi. d3 ual } \\
\text { in. di.(vi. d3 ual) } \\
\text { in. di.vi.(d3 ual) }\end{array}$ & $*$ & $\begin{array}{l}* \\
* \\
*\end{array}$ & $\begin{array}{l}* \\
* \\
*\end{array}$ & $\begin{array}{l}* * * \\
* * \\
* * \\
* *\end{array}$ \\
\hline
\end{tabular}

NONFINALITY $>>$ ALL-FT LEFT $>>$ UNEVEN-IAMB $>>$ PARSE-SYL $\rightarrow$ Optimal candidate 
104 Comparative Optimality Theory Analysis

Table 3b. NE: Three-Four Syllables (noun and verb)

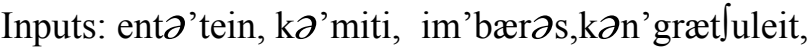
indI'vid3 uəl/

\begin{tabular}{|c|c|c|c|c|c|c|}
\hline $\mathrm{NO}$ & & & $\begin{array}{l}\text { UNEVEN- } \\
\text { IAMB }\end{array}$ & $\begin{array}{c}\text { NON- } \\
\text { FINALITY }\end{array}$ & $\begin{array}{c}\text { ALL-FT- } \\
\text { LEFT }\end{array}$ & $\begin{array}{c}\text { PARSE- } \\
\text { SYL }\end{array}$ \\
\hline $\mathrm{a}$ & $\sqrt{\infty}$ & $\begin{array}{l}\text { en.ta. (tein) } \\
\text { (en.ta). tein } \\
\text { (en). ta. Tein }\end{array}$ & & $*$ & $*$ & $\begin{array}{c}* * \\
* \\
* *\end{array}$ \\
\hline b & $\cos$ & $\begin{array}{l}\text { kJ. (mi). Ti } \\
\text { (kכ. mi). ti } \\
\text { kכ. mi. (ti:) }\end{array}$ & * & $*$ & $\begin{array}{l}* \\
* \\
\end{array}$ & $\begin{array}{c}* * \\
* \\
* * \\
\end{array}$ \\
\hline $\mathrm{c}$ & $\sqrt{\infty}$ & $\begin{array}{l}\text { em. (ba) . ras } \\
\text { (em. ba). ras } \\
\text { em. ba .(ras) }\end{array}$ & * & $*$ & $\begin{array}{l}* \\
* \\
\end{array}$ & $\begin{array}{c}* * \\
* \\
* * \\
\end{array}$ \\
\hline d & $\cos$ & $\begin{array}{l}\text { kən. (gra). } \tau u . l e i t \\
\text { (kən. gra). tu.leit } \\
\text { kən .gra. (tu.leit) } \\
\text { kən.gra. tu. (leit) }\end{array}$ & * & * & $\begin{array}{l}* \\
*\end{array}$ & $\begin{array}{l}* * * \\
* * \\
* * \\
* * *\end{array}$ \\
\hline e & $\operatorname{lis}_{\infty}$ & $\begin{array}{l}\text { in. di.(vi). dual } \\
\text { (in. di).vi. dual } \\
\text { in. di.(vi. dual) } \\
\text { in. di.vi.(dual) }\end{array}$ & * & * & $\begin{array}{l}* \\
* \\
*\end{array}$ & $\begin{array}{l}* * * \\
* * \\
* * \\
* *\end{array}$ \\
\hline
\end{tabular}

UNEVEN-IAMB $>>$ NONFINALITY $>>$ ALL-FT - LEFT $>>$ PARSE-SYL $\stackrel{s}{=}$ Optimal candidate

Notice that whereas on table 3a representing Standard British both NONFINALITY and ALL-FT-LEFT are higher in ranking or hierarchy than UNEVEN-IAMB, on table $3 \mathrm{~b}$ representing Nigerian English, UNEVEN-IAMB, in turn, is higher than ALL-FT-LEFTthe imperative for every foot to be at the left edge of a prosodic word.

Thus far, the last constraint conflict to be considered and or resolved before the final ranking 'is that between the anti lengthening constraint $-\mathrm{DEP}-\mu-\mathrm{IO}$ - and the imperative to parse all syllables by feet (PARSE-SYL). See tables $4 \mathrm{a}$ and $\mathrm{b}$ below: 
Table 4a. SBE: Two- Three Syllables (noun and verb)

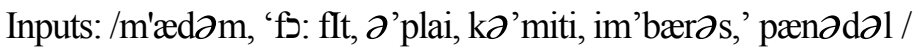

\begin{tabular}{|c|c|c|c|c|c|c|c|c|c|}
\hline No & & $\begin{array}{l}\mathrm{G}_{\mathrm{R}} \mathrm{W}_{\mathrm{D}} \\
\quad= \\
\mathrm{P}_{\mathrm{R}} \mathrm{W}_{\mathrm{D}}\end{array}$ & WSP & $\begin{array}{l}\text { FT- } \\
\text { BIN }\end{array}$ & \begin{tabular}{|} 
NON- \\
FINALIT \\
Y
\end{tabular} & $\begin{array}{l}\text { ALL- } \\
\text { FT. } \\
\text { LEFT }\end{array}$ & $\begin{array}{l}\text { DEP- } \\
\mu \text {-IO }\end{array}$ & $\begin{array}{c}\text { UNEVE } \\
\mathrm{N}- \\
\text { IAMB }\end{array}$ & $\begin{array}{l}\text { PARS } \\
\text { E-SYL }\end{array}$ \\
\hline$a$ & $\begin{array}{c}(\mathrm{mæ}) \cdot \mathrm{d} \partial \mathrm{m} \\
\text { (mæ. dəm) } \\
\text { mə. }(\mathrm{d}) \mathrm{m})\end{array}$ & & & & $\begin{array}{l}* \\
*\end{array}$ & $*$ & $\begin{array}{l}* \\
* \\
*\end{array}$ & $\begin{array}{l}* \\
* \\
*\end{array}$ & * \\
\hline $\mathrm{b}$ & $\begin{array}{r}\text { (fכ:) . fit } \\
\text { (fכ: . fit) } \\
\text { Fo. (fi: t) }\end{array}$ & & & & * & $*$ & $\begin{array}{l}* \\
* \\
*\end{array}$ & $\begin{array}{l}* \\
* \\
*\end{array}$ & * \\
\hline $\mathrm{c}$ & $\begin{array}{r}\text { क्षे. (plai) } \\
\text { (ə. plai) } \\
\text { (ə). plai }\end{array}$ & & & & $\begin{array}{l}* \\
*\end{array}$ & $*$ & $*$ & $*$ & * \\
\hline $\mathrm{d}$ & $\begin{aligned} \text { ॰ } & \text { kə (mi). ti } \\
& (\mathrm{k} \partial . \mathrm{mi}) \cdot \mathrm{ti} \\
& \text { Kə.mi. (ti:) }\end{aligned}$ & & & & $*$ & $\begin{array}{l}* \\
*\end{array}$ & $*$ & $*$ & $\begin{array}{l}* * \\
* \\
* *\end{array}$ \\
\hline e & $\begin{array}{r}\text { im. (bæ) . ras } \\
\text { (im. bæ). ras } \\
\text { im. bæ .(rəs) }\end{array}$ & & & & $*$ & $*$ & $\begin{array}{l}* \\
* \\
*\end{array}$ & * & $\begin{array}{c}* * \\
* \\
* *\end{array}$ \\
\hline $\mathrm{f}$ & $\begin{array}{r}\text { (pæ), nə. dəl } \\
\text { pæ.(nə). dəl } \\
\text { Pə .nə .(dəl) }\end{array}$ & & & & $*$ & $*$ & $\begin{array}{l}* \\
* \\
*\end{array}$ & $\begin{array}{l}* \\
* \\
*\end{array}$ & $\begin{array}{c}* * \\
* \\
* *\end{array}$ \\
\hline
\end{tabular}

$\mathrm{G}_{\mathrm{R}} \mathrm{W}_{\mathrm{D}}=\mathrm{P}_{\mathrm{R}} \mathrm{W}_{\mathrm{D}}$, WSP, FT-BIN $>>$ NONFINALITY $>>$ ALL-FT-LEFT $>>$ DEP- $\mu$ IO $>>$ UNEVEN-IAMB $>>$ PARSE-SYL

$\leftrightarrow=$ Optimal candidate

Table 4b. NE: Two- Three syllables (noun and verb)

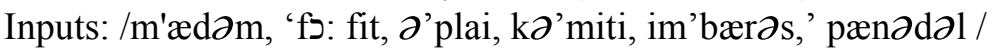

\begin{tabular}{|c|c|c|c|c|c|c|c|c|c|}
\hline No & & $\begin{array}{c}\mathrm{G}_{\mathrm{R}} \mathrm{W}_{\mathrm{D}} \\
= \\
\mathrm{P}_{\mathrm{R}} \mathrm{W}_{\mathrm{D}} \\
\end{array}$ & WSP & $\begin{array}{l}\text { FT- } \\
\text { BIN }\end{array}$ & $\begin{array}{l}\text { UNEVE } \\
\text { N-IAMB }\end{array}$ & $\begin{array}{l}\text { NON- } \\
\text { FINAL } \\
\text { ITY }\end{array}$ & $\begin{array}{l}\text { ALL- } \\
\text { FT-LFT }\end{array}$ & $\begin{array}{c}\text { DEP- } \mu- \\
\text { IO }\end{array}$ & $\begin{array}{l}\text { PARS } \\
\text { E-SYL }\end{array}$ \\
\hline $\mathrm{a}$ & $\begin{array}{l}\text { (ma). dam } \\
\text { (ma } \cdot \text { dam) } \\
\text { ma. (dam) }\end{array}$ & & & & * & * & $*$ & * & * \\
\hline b & 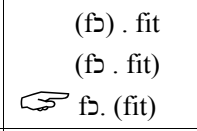 & & & & * & $\begin{array}{l}* \\
*\end{array}$ & $*$ & $\begin{array}{l}* \\
* \\
*\end{array}$ & * \\
\hline $\mathrm{c}$ & $\begin{array}{r}\text { a. (plai) } \\
\text { (a. plai) } \\
\text { (a). plai }\end{array}$ & & & & $*$ & $\begin{array}{l}* \\
*\end{array}$ & $*$ & $\begin{array}{l}* \\
*\end{array}$ & * \\
\hline
\end{tabular}


106 Comparative Optimality Theory Analysis

\begin{tabular}{|c|c|c|c|c|c|c|c|c|c|c|}
\hline No & & & $\begin{array}{l}\mathrm{G}_{\mathrm{R}} \mathrm{W}_{\mathrm{D}} \\
=\mathrm{P}_{\mathrm{R}} \mathrm{W}_{\mathrm{D}}\end{array}$ & WSP & $\begin{array}{l}\text { FT- } \\
\text { BIN }\end{array}$ & $\begin{array}{c}\text { UNEVEN } \\
\text {-IAMB }\end{array}$ & $\begin{array}{c}\text { NON- } \\
\text { FINALI } \\
\text { TY }\end{array}$ & $\begin{array}{c}\text { ALL-FT- } \\
\text { LFT }\end{array}$ & $\begin{array}{c}\text { DEP- } \mu- \\
\text { IO }\end{array}$ & $\begin{array}{c}\text { PARSE } \\
\text {-SYL }\end{array}$ \\
\hline d & $\sin$ & $\begin{array}{l}\mathrm{kJ} \text { (mi). ti } \\
\text { (kJ. mi). ti } \\
\text { kכ.mi. (ti) }\end{array}$ & & & & * & * & $*$ & * & $\begin{array}{c}* * \\
* \\
* *\end{array}$ \\
\hline $\mathrm{e}$ & $\cos$ & $\begin{array}{l}\text { em. (ba) . ras } \\
\text { (em. ba). ras } \\
\text { em. ba .(ras) }\end{array}$ & & & & * & * & $*$ & $\begin{array}{l}* \\
* \\
*\end{array}$ & $\begin{array}{l}* * \\
* \\
* *\end{array}$ \\
\hline $\mathrm{f}$ & $\operatorname{sis}$ & $\begin{array}{l}\text { (pa), na. dəl } \\
\text { pa .(na). dəl } \\
\text { pa .na .(dəl) }\end{array}$ & & & & $\begin{array}{l} \\
* \\
*\end{array}$ & $*$ & $*$ & $\begin{array}{l}* \\
* \\
*\end{array}$ & $\begin{array}{c}* \\
* \\
* * \\
\end{array}$ \\
\hline
\end{tabular}

$\mathrm{G}_{\mathrm{R}} \mathrm{W}_{\mathrm{D}}=\mathrm{P}_{\mathrm{R}} \mathrm{W}_{\mathrm{D}}$, WSP, FT-BIN $>>$ UNEVEN-IAMB $>>$ NONFINALITY, ALL-FTLEFT $>>$ DEP- $\mu$ IO $>>$ PARSE-SYL

$\rightarrow$ Optimal candidate

Notice also that on tables $4 \mathrm{a}$ and $\mathrm{b}$ above, the first three constraints before the double line are ranked highest (at the top) in the hierarchy of constraints in both varieties of English. Notice also, that where SBE has syllable final stress, NE does not deviate from that pattern. In other words, it maintains identical stress placement in this regard because of its preference for final syllable stress

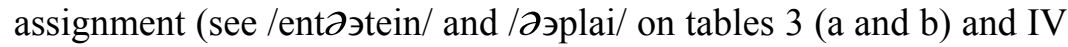
( $a$ and b) above respectively). Besides, whereas SBE ranks NONFINALITY above ALL-FT-LEFT, NE does not make such a clear 'distinction in the ranking of the two hence the decision to rank them equal in this variety. Their being higher or lower than each other depends largely on the kinds of example given in each instance, and in most cases, the variation is very insignificant (see tables $3 \mathrm{~b}$ and $4 \mathrm{~b}$ above, respectively). This will ultimately bring our constraints hierarchy for the two varieties to the configurations below:

SBE: $\mathrm{G}_{\mathrm{R}} \mathrm{W}_{\mathrm{D}}=\mathrm{P}_{\mathrm{R}} \mathrm{W}_{\mathrm{D}}$, WSP, FT-BIN $>>$ NONFINALITY $>>$ ALL-FT-LEFT $>>$ DEP- $\mu$ IO $>$ UNEVEN-IAMB $>>$ PARSE-SYL 
NE: $\mathrm{G}_{\mathrm{R}} \mathrm{W}_{\mathrm{D}}=\mathrm{P}_{\mathrm{R}} \mathrm{W}_{\mathrm{D}}$, WSP, FT-BIN $>>$ UNEVEN-IAMB $>>$ NONFINALITY, ALL-FT-LEFT >>DEP- $\mu$ IO $>>$ PARSE-SYL

\section{Conclusion}

This paper has examined the difference in primary stress assignment between Standard British English and Nigerian English using Optimality Theory. The analysis attempts to explain the difference in stress placement in these varieties in terms of the reranking or re-ordering of the universal constraints, especially the two most relevant constraints in this regard-NONFINALITY and UNEVEN-IAMB. Also, apart from seeing the difference spotted in this analysis only as a product of their different suprasegmental features in that English uses stress while most Nigerian languages use tone, there is a false hypothesization syndrome on the part of the Nigerian user of English as a second language. It is that whereas SBE targets only the primary stress of each word ignoring the other syllables, Nigerian English, in addition to targeting the primary stress on each word, spreads its effect to every syllable to the right of the stressed syllable in the word (See also Jowitt, 1992 \& Oyebade, 2000).This brings about the preference for UNEVENIAMB as against NONFINALITY.

In all, this study has demonstrated how the constraint ordering in Standard British English is 'naturally' re-ordered in Nigerian English. It is to be noted that the different constraint orderings notwithstanding, these constraints are the same, and are present in each of these varieties. As it were, resolving these often-conflicting universal constraints through ranking in strict dominance hierarchies to scan violability distinguishes one language from another, and in this instance, SBE from NE. As it were, language specific grammar is but a means of resolving conflicting universal constraints. In 
108 Comparative Optimality Theory Analysis

other words, what marks individual grammar is the order in which these constraints apply. This knowledge, it is believed, could lead to improved teaching, learning and overall better usage of English in Nigeria.

\section{References}

Adegbija, E. 1989. Lexico-semantic Variation in Nigerian English World Englishes 8.2,165-177.

. 1999 Nigerian Englishes: Towards a Standard Variety. A

Keynote Address Presented at the $5^{\text {th }}$ Conference of the International Association of World Englishes (IAWE). Chicago, IL: University of Illinois.

2004 The Domestication of English in Nigeria. In S. Awonusi \& E. Babalola (eds.), The Domestication of English in Nigeria (A Festschrift in Honour of Abiodun Adetugbo). Lagos: University of Lagos Press.

Akinjobi, A. 2002. Nigerian English or Standard English Suprasegmentals: The Question of which Variety to Teach. In S. Babatunde \& D. Adeyanju (eds.), Language, Meaning and Society: Papers in Honour of Prof. E. Adegbija. Ilorin: Haytee Press \& Publishing Co. Nig. Ltd.

Bamgbose, A. 1971. The English Language in Nigeria. In J. Spencer (ed.), The English Language in West Africa 35-48. Ibadan: University of Ibadan Press.

. 1982. Standard Nigerian English: Issues of Identification. In

B. Kachru (ed.), The Other Tongue: English Across Cultures. Urbana, IL: University of Illinois Press.

1995. English in the English Environment. In A. Bamgbose

et. al (eds.), New Englishes. Ikeja: Mosuro Publishers.

Banjo, A. 1969. Towards a Definition of Standard Nigerian English An Address at the Linguistic Society of West Africa Congress 
165-175, Abidjan: Abidjan University.

1975. Varieties and Standardization: The Case of English in Nigeria. WAMCA. . 1995. On Codifying Nigerian English: The Research So Far. In A. Bamgbose et al. (eds.), New Englishes: A West African Perspective. Ibadan: Mosuro Pulishers.

Bermudez-Otero. R. \& P. Honeybone. 2004. Phonology and Syntax: A Shifting Relationship. Lingua 116, 543-561.

Chomsky, N. 1992. A Minimalist Programme for Linguistic Theory. MIT Working Papers in Linguistics 1 . Department of Linguistics and Philosophy.

Chomsky, N. \& M. Halle. 1968. The Sound Pattern of English. New York: Harper and Row.

Clark, J. \& C. Yallop. 1994. An Introduction to Phonetics and Phonology. Oxford: Blackwell

Dunstan, E. 1969. Twelve Nigerian Languages. London \& Harlow: Longmans, Green \& Coy Ltd.

Gimson, A. 1980. An Introduction to the Pronunciation of English. London \& New York: Routledge.

Goldsmith, J. 1976. Autosegmental Phonology. Bloomington, IN: Indiana University Linguistic Club.

. 1990. Autosegmental and Metrical Phonology. Oxford: Blackwell Publishers.

Halle, M. 1973. Stress Rules in English: A New Version. Linguistic Inquiry 4, 51-64.

Halle, M. \& J. Vergnaud. 1990. An Essay on Stress. Cambridge, MA: MIT Press.

Hammond, M. 1999. The Phonology of English: A Prosodic Optimality-theoretical Approach (The Phonology of the World's Languages). London: Oxford University Press.

Hayes, B. 1981. A Metrical Theory of Stress Rules. Bloomington, IN: Indiana University Linguistic Club. . 1987. A Revised Parametric Metrical Theory. In J. 
110 Comparative Optimality Theory Analysis

McDonough \& B. Plunket (eds.), Proceedings of the North East Linguistic Society 17, 274-89.

1995. Metrical Stress Theory: Principles and Case Studies.

Chicago, IL: University of Chicago Press.

Hogg, R. \& C. McCully. 1985. Metrical Phonology: A Course Book.

Cambridge: Cambridge University Press.

Hyman, L. 1975. Phonology: Theory and Analysis. New York: Holt, Rinehart \& Winston.

Jowitt, D. 1991. Nigerian English Usage: An Introduction. Ibadan: Longman.

Kager, R. 1999. Optimality Theory. Cambridge: Cambridge University Press.

Katamba, F. 1989. An Introduction to Phonology. London: Longman.

Kujore, O. 1985. English Usage: Some Notable Nigerian Variations. Ibadan: Evans Brothers.

1990. Nigerian English Usage: Analogies, Aberrations and the Tyranny of Idea. Journal of the Nigerian English Studies Association 10.1.

Ladefoged, P. 1967. Three Areas of Experimental Phonetics. London: Oxford University Press.

Liberman, M. \& A. Prince, 1977. On Stress and Linguistic Rhythm Linguistic Inquiry 8, 249-336.

Lieberman, P. 1970. Towards a Unified Phonetic Theory. Linguisti Inquiry 1, 307-322.

McCarthy, J. 1982. Nonlinear Phonology: An Overview. Glow 8. Austin \& Amherst: University of Texas \& University of Massachusetts. .1993. A Case of Surface Constraint Violation. Canadian Journal of Linguistics 38, 169-195. 2002 A Thematic Guide to Optimality Theory. Cambridge: Cambridge University Press.

McCarthy, J. \& A. Prince. 1993a. Prosodic Morphology 1: 
Constraint Interaction and Satisfaction. Unpublished Manuscript, Amherst \& New Jersey: University of Massachusetts \& Rutgers University. . 1993b. Generalized Alignment. Yearbook in Morphology,

79-154.

.1994. The Emergence of the Unmarked Optimality in

Prosodic Morphology. In M. Gonzalez (ed.), NELS 24

Proceedings of the North East Linguistic Society, Amherst, MA: University of Massachusetts.

Odumuh, A. 1984. Educated Nigerian English as a Model of Standard Nigerian English . World Englishes 3, 1-14.

Omachonu, G. 2001. Inconsistencies in the English Orthography: Implications for teaching and Learning English Phonology in Nigeria. Teacher Education Journal (TEJ) 2.2, 20-25.

. 2001 Igala Phonetics and Phonology: An Overview. MA.

Thesis, Department of Linguistics and Nigerian Languages.

Nsukka: University of Nigeria.

Omachonu, G. \& Y. Ibrahim. 2001. Improving Your Performance in Oral English. Nsukka: AP Express Publishers.

Oyebade, F. 1997. From Rule-based to Constraint-based Analysis:

Trends in Phonology (Sub-title: OCP Violation Avoidance in

Yoruba). Commissioned Paper Presented at the 17th

Conference of the Linguistic Association of Nigeria, Usman Dan Fodio University, Sokoto. Nov. 4-7, 1997. 1998. A Course in Phonology. Ijebu-Ode: Shebiotimo Publications.

2000. A Comparison of the Phrasal Rhythm of Standard

English and Nigerian English: A Metrical Phonology Analysis'.

In E. Adegbija (ed.), Ilorin Journal of Language and Literature 4, 57-71.

Prince, A. \& P. Smolensky. 1993. Optimality Theory: Constraint Interaction in Generative Grammar. Ms. Rutgers University, New Brunswick and University of Colorado, Boulder. 
112 Comparative Optimality Theory Analysis

Pulleyblank, D. 1994. Neutral Vowels in Optimality Theory: A Comparison of Yoruba and Wolof. Ms. University of British Columbia.

Roach, P. 1991. English Phonetics and Phonology. Cambridge: Cambridge University Press.

Tesar, B. \& P. Smolensky. 2000. Learnability in Optimality Theory. Cambridge, MA: MIT Press. 